\title{
Parian Figüratif Porselenleri
}

\author{
Efe TÜRKEL*
}

Özet

On dokuzuncu yüzyılın ortalarından itibaren, İngiltere'de geliştirilen Parian porselen bünyesiyle üretilen porselen figürler, heykel sanatının seri üretim aracılığıyla gündelik yaşam alanlarında popüler bir unsur olarak yaygınlaşmasını sağlamış, bu anlamda heykel sanatına yönelik algıya da farklı bir soluk getirmiş, biçimsel ve üslup özelliklerinden ziyade ait olduğu döneme devrim niteliğindeki teknik özellikleriyle katkıda bulunmuştur. Bu porselen bünye sayesinde özellikle Victorian Dönem'de (1837-1901) büst, portre, figürlü vazo ve sürahiler veya zengin kompozisyona sahip çok figürlü çalışmalar orta sınıfın evlerinde seri üretilmiş heykeller ve dekoratif unsurlar olarak kendilerine yer bulmuşlardır. Parian porselen figürlerine olan yoğun ilgi İngiltere'deki üreticiler arasında büyük bir rekabet yaşanmasına da sebep olmuştur. Bu rekabet beraberinde farklı bünyelerdeki porselenlerin ve seramik ürünlerin geliştirilmesine de öncülük etmiştir. Bu çalışmada, sahip olduğu plastik değerler ve malzemenin niteliği açısından hem sanatsal hem de endüstriyel değerleriyle zirve yapan bu eserlerin Neoklasik dönem anlayışı ve sanat birlikleri sayesinde toplumla kurduğu ilişkiyle beraber Avrupa'daki benzerlerinden farklı olarak seramik ve heykel sanatına getirdiği teknik yenilikler de incelenmiştir.

Anahtar Sözcükler: Parian, Neoklasizm, Porselen, Figüratif Heykel, Seramik.

\section{Parian Statuary Porcelain}

\section{Abstract}

Since the mid-nineteenth century, porcelain figures produced by Parian porcelain body, which was developed in England gave a new impulse to the art of sculpture by popularizing them for living rooms and, contributed in a revolutionary way to its period rather than merely touching on formal and stylistic features. Thanks to this porcelain body, busts, portraits, vases and jugs with figures or multi-figured artworks in rich composition took place as mass-produced sculptures and decorative pieces in middle class homes especially in Victorian period (1837-1901). Great interest in Parian porcelains created a great competition among the manufacturers in England. This competition pioneered the development of porcelain and ceramic products in different organizations. In this paper, these works which reached a summit point in both artistic and industrial levels in terms of their plastic value and material quality are examined in relation to their interaction with society provided by the artistic associations and artistic understanding of Neoclassical period. Additionally, technical innovations brought to ceramic and porcelain art by means of these works, which are in a different manner from their counterparts in Europe, are examined.

Keywords: Parian, Neoclassicism, Porcelain, Figurative Sculpture, Ceramic. 


\section{Giriş}

İngiltere, on sekizinci ve on dokuzuncu yüzyıllar arasında güçlü ve baskın bir dünya ülkesine dönüşmüş, bununla beraber İspanya Veraset Savaşı ve Yedi Yıl Savaşı gibi askeri alanda kazanmış olduğu başarıların da sayesinde deniz aşırı bölgelerde de üstünlük kurmuştur. Bu dönemde İngiliz ihraç ürünlerinin fiyatı ikiye katlanmış, tarım ve endüstri üretimi yüzde atmış oranında artmıştır. Üreticiler ve meslek odaları Kral I.George tarafından desteklenmiş, bu sayede orta sınıfın gelirindeki artışla beraber lüks tüketimi de çok hızlı bir biçimde artmıştır, kimi tarihçilere göre "tüketim toplumu” teriminin ilk çıkış noktası da bu döneme dayanmaktadır. Bu ekonomik yükseliş, İngiltere'de özel ev eşyalarına sahip olma modası yaratmış, bu da dekoratif sanatların hızla gelişmesini sağlamıştır. ${ }^{1}$ On sekizinci yüzyıl İngiltere endüstrisinin standartlarını yükseltmek amacıyla Kraliyet Sanat Kurumu (The Royal Society for the Encouragement of Arts, Manufactures and Commerce-1754) gibi kuruluşlar yapılandırılmış, buralarda endüstriyel sanatlardaki yeni teknolojilerin paylaşıldığı forumlar düzenlenmiş, tasarımcılara ödül, teşvik ve eğitime yönelik burslar verilmiştir (Coutts, 2001: 141). Bu girişimler, İngiltere'de sanat-tasarım alanında üretilmiş çalışmaların ticari bir değeri olduğu bilincinin de tamamen yerleştiğinin kanıtı olmuştur. Bu çalışmada sadece İngiliz porselen üreticilerinin değil, Victorian Dönem'de Neoklasizm etkisindeki İngiltere'de üst ve orta sınıfın sanat piyasası üzerindeki izleri ele alınmış, Parian figüratif heykellerinin de bu süreçteki rolü görsellerle incelenmiştir.

İngiltere'de Porselen Figür Üretimi ve Neoklasik üslubun Etkileri Avrupa'nın öncü seramik üreticilerinden biri olan İngiltere'de on sekizinci yüzyılın ortalarına kadar porselen ürünler Uzak Doğu, Fransa ve Almanya'dan ithal edilmekteydi. Özellikle bu dönemde porselen, ev dekorasyonu için çok önemli bir unsurdu ve popüler hale gelmişti, öyle ki bazı evlerde porselen ürünlerin ağırlıklı olduğu veya koleksiyonunun yapıldığı özel odalar tasarlanmaktaydı. Porselen figürler şömine raflarında dekorasyonu tamamlayıcı unsurlar olarak çok kullanılmış, İngiltere'de özellikle Çin'den ithal edilenler ön plana çıkmıştı. Porselene olan bu talep kısa zamanda Birleşik Krallığın tümünde karşılık bulmuş, 1744'te Nicolas Sprimont tarafından kuru- lan Chelsea'deki fabrikada ilk porselen üretimi gerçekleştirilmiştir. ${ }^{2}$ Yumuşak porselen bünyelere sahip bu ürünlerin en büyük özelliği hem figüratif öğelere sahip oluşları hem de kullanım amaçlı olarak tasarlanmış olmalarıdır (Resim 1). Sadece figüratif amaçla tasarlanmış porselenler sayıca daha azdır. Özellikle 1760 'larda yapılmış olan figür grupları ve vazolar detaylarla donatılmış, renkli ve Sévres tarzı altın yaldızlıdır. François Boucher’ın gravürlerinden öykünerek yapılan 'Müzik Dersi' ve 'Dans Dersi' isimli porselen heykeller bunlar arasında en göze çarpan ve dönemi iyi yansıtan örneklerdir. 1750'de Derby'de kurulan fabrika Chelsea'deki porselen fabrikasının üretmiş olduğu heykellere rakip olacak kalitede porselen figürler üreten önemli üreticilerdendi. Bu fabrika, o dönemin modasını yansıtan kıyafetler giymiş, hanımefendi ve beyefendileri veya Rokoko stilindeki Çin figürleriyle ünlenmiştir (Resim 2) (Coutts, 2001: 142-151).

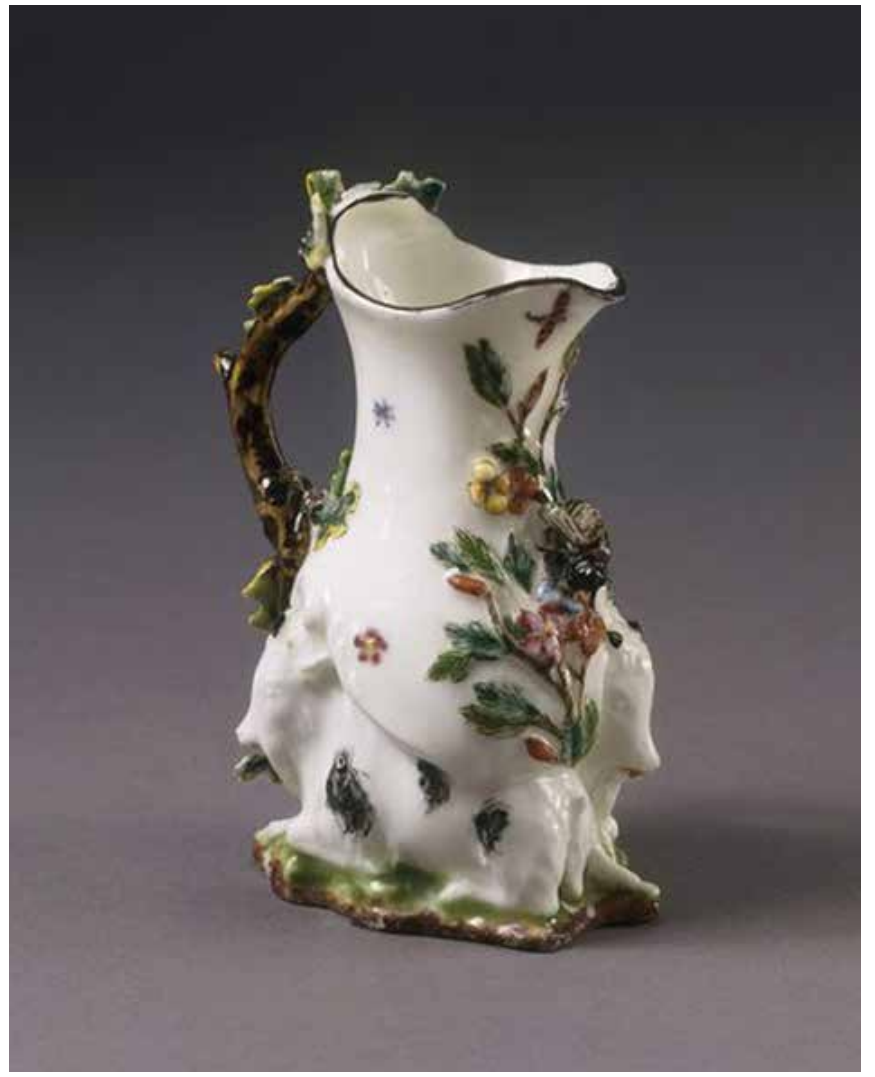

Resim 1. 'Keçi ve arı' sürahi. Chelsea Porselen Fabrikası'nda yumuşak porselen bünyeyle 1745 yılında üretilmiştir. Emaye dekorlu eserin tasarımcısı Nicholas Sprimont’tur. 

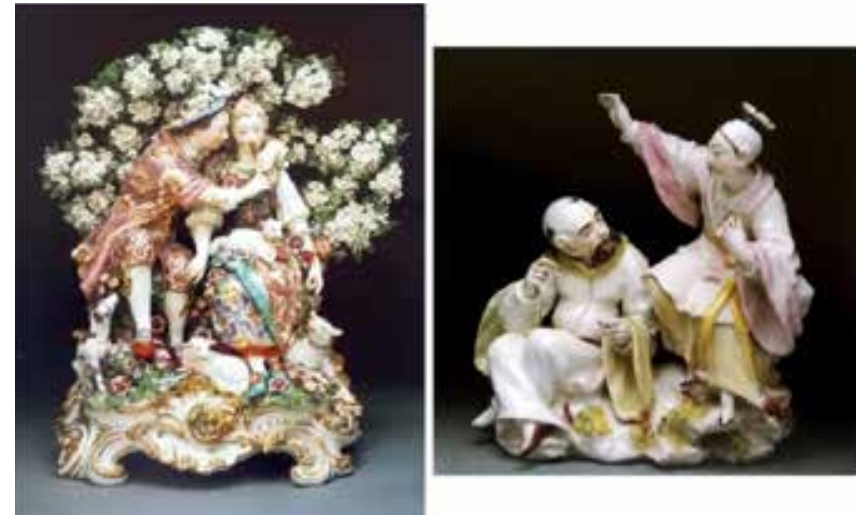

Resim 2. Chelsea Porselen Fabrikası'nda üretilmiş 'Müzik Dersi' isimli ve Derby Porselen Fabrikası'nda üretilmiş Çin figürlü Sévres tarzı porselen figür grupları.

Batı Avrupa sanatında Klasik Sanatın etkileri, on beşinci yüzyıldan on dokuzuncu yüzyıla kadar görülmüş, bu etkiler porselen üretimine de yansımıştır. Bu anlayış, özellikle iç pazardaki talepler doğrultusunda 'klasik üsluptan daha klasik' tarzda taklit eserler ortaya çıkmasını da beraberinde getirmiştir. On sekizinci yüzyılda daha da canlandırılan bu akım bazı yönleriyle eklektik görünmektedir, öyle ki çok geniş bir kaynaktan ilham alan Neoklasizm, toplumunun form ve normlarına uygun, modern yaşam biçimine uyum sağlayacak, eski üsluba ait eserler ortaya koyma girişimindedir. Klasik sanatın yeniden dirilişi 'Aydınlanma' olarak bildiğimiz, on sekizinci yüzyıl düşünce akımlarıyla yakından ilişkilidir. Bu düşünce dünyayı, duygusal veya dini yönden ziyade daha rasyonel ve bilimsel gözleme dayalı olarak anlamayı işaret eden entelektüel ve sosyal bir harekettir. Toplumsal sorumluluk ve vatandaşlık gibi bireysel olgular, kutsal krala bağlılık ve monarşik yönetimin getirdiği benzeri inançların yerini almaya başlamıştır. Bu sebeple on sekizinci yüzyıldan sonra, Klasik üslubun natüralist özelliği diğer tasarım ürünleriyle beraber porselen üretimine de yansımış ve pervasız olarak tanımlanabilecek aşırı serbest Rokoko üslubuna karşılık klasik dönem sanat disiplini daha üstün görülmeye başlanmıştır (Coutts, 2001: 169).

Neoklasizmin yapı olarak barındırdığı karmaşa halen tarihçilere çözümlemeleri için yeni alanlar önermektedir. Neoklasizmi başlatan sanatçılar için bu biçem, Antikitenin ve Yunan tarzının en saf haliyle geri dönüşü olarak ortaya çıkmış ve bu sanatçılar tarafından Barok ve Rokoko kesin bir şekilde reddedilmiştir. İlk eserlerin hemen hemen hiç biri Yunan orijinallerinin kalitesinde değildir ve Batı Avrupa'daki öncü yazarlar ve sanatçıların hiçbiri de henüz Yunan Yarımadası'nı ziyaret bile etmemiştir. Bu öncülerin görüşleri İtalya'da bulunmuş olan Antik Dönem eserleri üzerine şekillenmiştir - ki bunların bazıları Yunan orijinallerinin yorumlanmış versiyonlarıdır- fakat bunların da çoğu İtalya'daki ikinci sınıf ustalar tarafından yapılmıştır. Bunun da ötesinde Yunan sanatına gösterilen yapmacık saygı aşırı tutkulu bir duyarlılıkla birleşince ortaya çıkan şey Yunan olmayan, taklit, yoruma açık bir üsluptur (Whinney, 1992: 277).

$\mathrm{Bu}$ akımın Britanyalı porselen üreticilerine etkileri incelendiğinde; Avrupa'nın diğer üreticilerinde oluğu gibi saplantılı bir biçimde ve geniş bir skalada Neoklasik vazo üretimi yapıldığı görülmüştür. Özellikle şömine rafı süsü olarak tabir edilen ve o dönemde çok moda olan Neoklasik üsluptaki ev dekorasyon ürünlerinin üretiminde Bow, Chelsea, Derby ve Wedgewood fabrikalarının çekişmesi ön plandadır. Özellikle bu fabrikalardan çıkan yapıtlar günümüz müze koleksiyonlarının önemli parçalarındandır (Re$\operatorname{sim} 3)$.
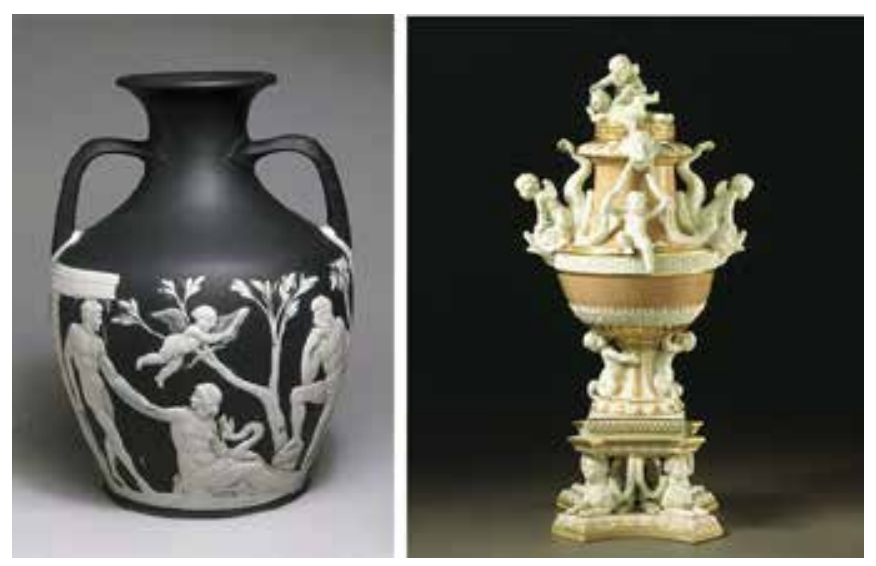

Resim 3. Victoria \& Albert Müzesi koleksiyonundan Neoklasik üslupta yapılmış Wedgwood markalı 'Portland Vase' ve Derby Porselen Fabrikası'na ait figürlü vazo.

Neoklasik üslup Avrupa'da olduğu gibi, Britanya'daki tüm sanat ve tasarım alanlarında on dokuzuncu yüzyılın ilk yarısında oldukça baskın duruma gelmiş, özellikle heykel sanatında yüzyılın sonuna kadar ağırlığını korumuştur. Yine Sévres'in yarattığı modaya uygun olarak sırsız figüra- 
tif porselen heykeller de bu dönemde çok sayıda üretilmiştir. Ancak Britanya'da porselen üretiminin başlangıcından yaklaşık bir yüz yıl sonra özel bir bünyeye sahip ve adını Klasik Dönem heykellerinde kullanılan Parian mermerine benzeyen görüntüsünden alan Parian figür heykelleri üretilmeye başlanmıştır.

\section{Parian Figüratif Porselen Heykellerinin Doğuşu}

Victoria Dönemi'nde, Hükümet ve Londra Sanat Birliği, görsel sanatları sınıflar arası sosyal uyum yaratmak ve İngiliz ticari üstünlüğünü korumak adına ciddi biçimde desteklemişlerdir. Bunun yöntemini de kitleler arasında sanatı teşvik etmek, sınıfsal ilgi alanlarını geliştirerek başarmayı hedeflemişlerdir. üretici sınıfın, sanat ve endüstri fuarları için daha güzel ve estetik ürünlerle katılmaya teşvik edilmesi amaçlanmış, ister üretici ister ressamlar tarafından üretilsin, İngiliz malları için yeni bir pazar yaratılması hedeflenmişti ve ekonomik manipülasyonun yolu, sosyal anlamda manipülasyon yaratmaktan geçiyordu. Bu süreç, iki dönem İngiltere başbakanlığı yapmış Sir Robert Peel öncülüğünde sistemli bir biçimde devam ettirilmişti. Londra Sanat Birliği'nin bu dönemdeki faaliyetleri, hem sanatçı tasarımcıları destekler nitelikteydi hem de üst-orta sınıfın evlerine girecek eserlerle bir ticari döngü oluşturma hedefliydi. Parian porselen heykellerinin yakalayacağı ticari başarıyı başlatacak olan etkenlerden biri de Londra Sanat Birliği'nin bir girişimiydi (Hurtado, 1993: 1).

İngiltere'de on dokuzuncu yüzyılın ortalarına gelmeden önce mermer heykel ve büst gibi sanat eserlerini evlerinde sergilemek maksatlı alabilenler zengin sınıfıydı, orta sınıfın üstündekiler de benzer türde gevrek, tebeşirimsi ve bisküvi diye adlandırılan porselen imitasyonları evlerine alıp sergileyebiliyorlardı ${ }^{3}$ (Barker, 1985: 3). Parian bünyenin icadından önce, yumuşak porselen bünyeler bu tip figürlerin üretiminde kullanılıyordu. Özellikle İngiltere'deki üreticilerin sıklıkla kullandığı bone china ${ }^{4}$ bisküvisi daha önceden kullanılan yumuşak porselen bünyelerin estetik değerlerine ulaşamıyordu. Figüratif heykellerin üretimi için pek çok firma yeni bünyeler geliştirme çabasındaydı ve çoğu da başarısız olmuştu. İşte bu dönemde Parian bünyesinin bulunması seramik heykelciliğinde bir devrimi başlattı (Copeland, 2007: 92). Parian bünyesinin icadından sonra Kraliçe Victoria, Charles Dickens ve döneme ait güncel kişiliklerin büstleri daha ucuz, doku olarak daha yumuşak, bisküvi diye adlandırılan bünyeden çok daha kaliteli ve mermeri taklit eden görüntüsüyle orta sınıfın da evlerine girmeye başladı (Resim 4).

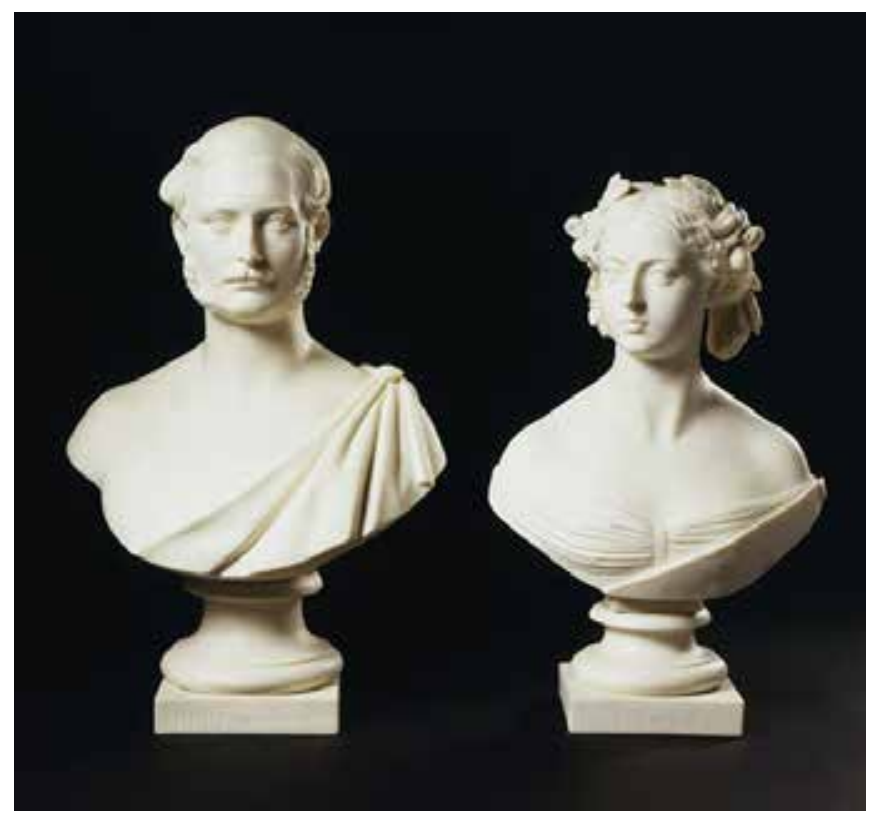

Resim 4. Prens Albert ve Kraliçe Victoria'nın büstleri. $32 \times 21,1$ x $11,5 \mathrm{~cm}$. ve $29 \times 18,3 \times 11 \mathrm{~cm}$. Minton \& Co. 1862. Victoria \& Albert Müzesi koleksiyonu.

Öyle ki, bu moda, İngiltere Krallığı'nın zirve yaptığı dönemde Kraliçe Victoria'nın büstünü taşıyan vazoların yapıldı̆̆ı, dekoratif ve kullanım eşyalarının büyük ilgi gördüğü bir dönem olan Victorian ve Edwardian olarak adlandırılan dönemlerde zirve yapmış, özellikle portre ve büst olarak üretilen eserlerdeki kalite Birinci Dünya Savaşı'nın olduğu dönemlere kadar sürmüştür. Parian'ı tanımlarken biçimsel özelliğinden ziyade malzeme özelliğinin vurgulanmasında fayda vardır. Parian bahsedildiği üzere ismini, Yunanistan'ın Ege Denizi'ndeki adalarından biri olan Paros'taki Elias Dağı'nın mermerlerinden almıştır. ${ }^{5}$ Görüntüsü ve dokusu itibariyle bu mermerden üretilmiş hissini vermektedir. Yüzeyi yumuşak, mat ve hafif fildişimsi renktedir. Günümüze kalan örnekler ağırlıklı olarak, büstler, portreler, küçük figürler, figürlü veya süslü vazolar, sürahiler, madalyonlar ve hayvanların ve insanların betimlendiği girift kompozisyona sahip figürler grubundan oluşmaktadır (Resim 5) (Barker, 1985: 3). 
Parian, çoğunlukla Fransa Sévres'de üretilmiş porselen bisküvi figürlerin geliştirilmesi fikrinden yola çıkılarak üretilmiştir. ${ }^{6}$ Bu dönemde yaygın şekilde üretilen bu porselen figürlerin dezavantajları, genellikle, kalın cidarlı, ağır, kırık beyaz renkte pürüzlü bir yüzeye sahip olmalarıydı. Tüm bu dezavantajları Parian bünyesi ortadan kaldırmıştı. Ayrıca yüksek oranda pekişmiş bünyesinin güzelliğinin ötesinde biçimlendirmesi de kolaydı ve bu sayede gerçek gibi görünebilen büstlerin yapımına da elverişliydi.
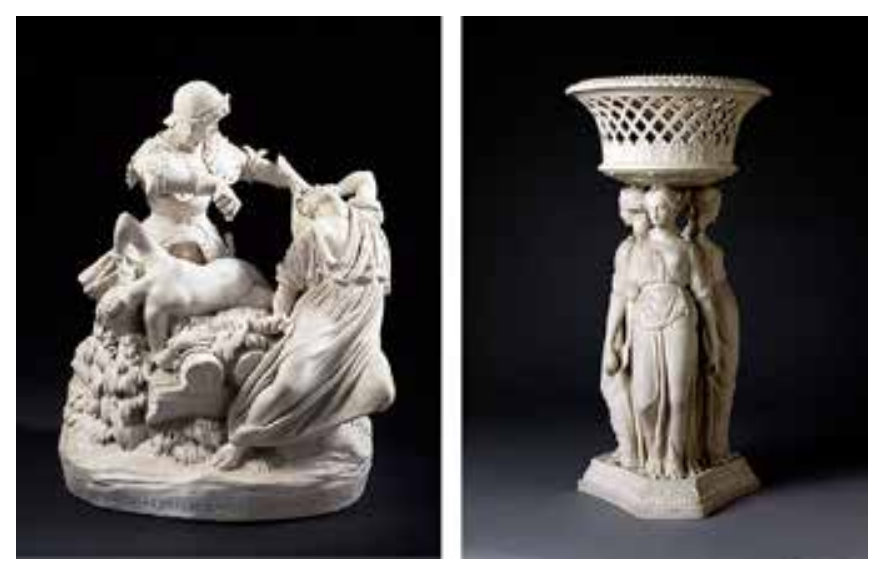

Resim 5.Victoria and Albert Müzesi koleksiyonunda yer alan Coalport Porselen Fabrikası markalı $46 \mathrm{~cm}$ yüksekliğinde 'The Faerie Queene' (1852) ve Copeland'a ait dekoratif figürler grubu. (1851)

Porselen bünyenin o döneme ait bileşenleri temel olarak, silika ve alkaliden oluşan bir eritici karışımının, mermer ve beyaz kil ile karışımından oluşmaktaydı. Bu dönemde üretilen çalışmalarda ilk olarak plastik beyaz kil ve camın çok miktarda bünyede kullanılmasıyla Parian'ın karakteristiği olan daha şeffaf bir bünye elde edilmiştir. Parian bünyelerin reçeteleri firmadan firmaya değişiklikler göstermiştir (Barker, 1985: 5).

Kesin olarak, 1840’lı yıllarda bulunduğu düşünülen Parian porselen bünyesinin kökenleri hakkında farklı tartışmalar yaşanmıştır. Mintons Ltd. ve T.\&R. Boote bu bünyeyle üretimi ilk kendilerinin yaptığını iddia etse de otoriteler bu bünyeyle yapılan ilk üretimin Copeland \& Garrett tarafından yapıldığını belirtirler (Copeland, 2007: 16). Elisabeth Cameron (1986: 225), 'Encyclopedia of Pottery and Porcelain' adlı kitabında ilk üretimi Copeland'ın 1846'da7 yaptığını belirtir ve bu bünyeyi şöyle tanımlar: “...Parian porselen bünyeleri, mat beyaz, yarı şeffaf kimi zaman hafif sırlıdır. ${ }^{8}$ Bünyeler genellikle mermersi, pürüzsüz bir dokudadır ve bisküvisi saf beyaz görünümündedir...”. Cameron, Parian 'ismini' kullanan ilk şirketin de Minton olduğunu belirtir. Parian porselen bünyesi ilk olarak figür heykeli ve grupları için daha sonraları ise sıklıkla sırlı porselenlerin merkezinde dekoratif unsur olarak kullanılmıştır. Minton bu dönemde Marc-Louis Solon'un Parian porselen bünyesini geliştirerek pâte-sur-pâte ${ }^{9}$ tekniğinde uyguladığı sert porselen bünyelerde bol miktarda altın yaldızlı yemek takımını üretmiştir. 1840'larda aynı zamanda Parian bünyenin bir versiyonu olan sert porselen bünye ile de benzer işler üretilmiştir. Belleek Fabrikası her iki bünyeyle de ürünler veren ilk firmadır ve devamında da yanardöner sırlı benzer bir bünye üretmiştir (Resim 6). 1890’lardan sonra İngiltere'deki üretimin azalmasına rağmen Robinson \& Leadbeater yirminci yüzyıla kadar üretimini kesintisiz sürdürmüştür. Diğer Avrupalı üreticiler Rörstrand ve Gustavsburg fabrikalarıdır (Cameron, 1986: 225).
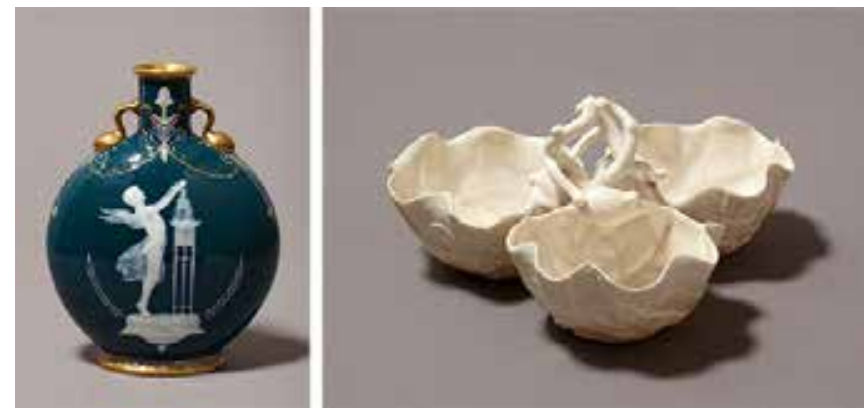

Resim 6. Louis Solon imzalı, pâte-sur-pâte tekniğinin uygulandığı altın yaldızlı şişe (1875) ve Belleek firmasına ait deniz kabuğu biçimli lüsterli Parian kâseleri (1868).

1840'larda orta sınıfın servetinin büyümesiyle aristokratların evlerinde sergileyecekleri küçük heykellerin üretimini karşılayacak uygun bir pazar da ortaya çıkmasıyla, öncü üreticiler, mermeri andıran seramik heykelleri üretmenin arayışına girmişlerdi ve bunların aynı zamanda pazar taleplerini karşılayacak yeterli miktarlarda ucuz maliyetli olmasını hedeflemişlerdi. Üreticiler arasından John Turner ve Josiah Wedgewood, stoneware 10 ve siyah bazalttan ürettikleri büst ve figürlerle bu taleplere farklı teknik ve üsluplarla karşılık vermişlerdi. Bu çabalar Parian porselen heykellerinin üretilmesini tetiklemişti. Ancak diğer üre- 
ticilerin de benzer bünye reçeteleriyle ürettikleri figürler söz konusu olunca, Copeland \& Garett firmasından Thomas Battam, bu heykellerin ve büstlerin üretildiği stonechi$\mathrm{na}^{11}$ reçetesini temel alıp bünyede değişikliklere giderek söz konusu figürlere yeni bir soluk getirecek olan Parian bünyesini geliştirdi (Copeland, 2007: 21).

1989 yılında yayımlanan, 'The Parian Phenomenon' adlı kitabın yazarı ve editörü, ünlü İngiliz eski eserler uzmanı Paul Atterbury de bu bünyenin ilk olarak 1842'de Copeland firması tarafından geliştirilen, detaylı modellerin çok sayıda üretilebilmesini sağlayan mermersi görünümlü saf beyaz bir materyal olduğunu, Minton firmasının ise kendi geliştirdiği benzer bünyeyi 1846 yılından itibaren kullanmaya başladığını belirtir. Paul Atterbury'nin Copeland'ın bünyeyi bulmasına ilişkin belirttiği tarih Elisabeth Cameron'ın belirttiği tarihten dört sene öncedir. Çeşitli kaynaklardan yapılan araştırmalara dayanarak bu bünyenin 1842 'de ilk olarak Copeland firması tarafından bulunduğu ve geliştirildiği, diğer firmaların da benzer reçetelerle ileriki yıllarda eserler ürettiği söylenebilir. Bu konuya ilişkin en eski tarihli kayıt 1851'de R. Hunt tarafından kaleme alınmış, 'The Handbook to the Official Catalogues of Great Exhibition' isimli yayındır. Burada seramik üretiminde mermeri taklit etme fikrinin ilk olarak Copeland firmasının sanat direktörü Thomas Battam tarafından ortaya atıldığı ve uygulamaya geçirildiği yer almaktadır. Ancak bu yayında 'figüratif heykel' terimi yer almaz.

Ocak 1845 tarihli The Art Union dergisinde Londra Sanat Birliği'nin bir raporu yayınlanır. Mermeri taklit etme fikrinin ilk olarak kayıt altına alındığı ve yayımlandığı bu raporda şu ifadeler yer alır; “... Kurul sıklıkla üreticiler ve Sanat arasındaki yakın bağı ve birbirlerine destek vermeleri konusundaki önemi dile getirmektedir. İlk adım olarak, bazı güzel heykelleri küçük boyutlara indirgemeyi kararlaştırdılar ve Messrs. Copeland \& Garret tarafından üretilen belirli sayıdaki kopyaları stonechina olarak piyasaya çıkardılar ...”

Bu tarihlerde Neoklasik üslup örneğinde yontulmuş heykellerin küçük birer kopyasını satın almak da moda haline gelmiştir. Ancak bazı heykeller William Turner'ın patentli stonechina bünyesine yakın formüllerde sırsız bünyelerden yapılmıştır. Başlangıçta Parian ve stonechina bünyelerden üretilmiş heykellerin kayıtlarda çok belirgin bir ayrıma tabi tutulduğu düşünülmemektedir. Bazı Parian bünyelerin stonechina olarak üretildiği düşünülerek kayıtlara geçmiştir.

Temmuz 1851 tarihli The Staffordshire Advertiser dergisinde ise R.Hunt'ın gözden geçirilmiş ve yenilenmiş şu açıklamaları yer almaktadır:

"... Mermeri seramik üretiminde taklit etme fikri Copeland porselen fabrikası yöneticilerinden Bay Thomas Battam tarafından 1842 'de ortaya konmuştur. Sutherland Dükü Ağustos 1842 'de yapılmış ilk örneği görmüş ve müşterisi olmuştur... Copeland'ın reçetesi ... ${ }^{12}$

$\% 60.35$ Silika

\%32.00 Alümina (Kaolin)

$\% 4.16$ Soda

$\% 2.55$ Potas

Eser miktarda magnezyum oksit, kalsiyum oksit ve demir oksit."

Ancak bu reçetenin henüz tam olarak mükemmel olmadığına da değinilmiştir. Bu, Copeland \& Garret Firmasının kullandığı düşünülen 1842 tarihli kayıtlara geçmiş ilk reçetedir. (Copeland, 2007: 16-17'den).

Ancak 1993 yılında Worcester'daki Dyson Perris Müzesi'nin Küratörü Harry Frost'un, Coalport porselen fabrikasının sanat direktörü Thomas John Bott'a ait el yazısının bulunduğu kitapçıktan ortaya çıkardığı bir kayıttaki reçete 1845 tarihli Copeland firmasının envanterinde bulunan reçete kitapçı̆̆ındakiyle aynıdır. Bu reçetenin içeriği şöyledir;

'Frit'

50 lbs $^{13}$ Lynn kumu ${ }^{14}$ veya Kuvars

30 lbs Sodyum Feldspat

8 lbs Potasyum Karbonat

'Bünye'

$\% 40$ China Clay 15

\% 40 Kalsine Soda

\%13.3 Frit

\%6.7 Kuvars Camı 
Parian üretimine ait ilk reçetenin bu olduğu düşünülebilir. Bu figürlerin yapımına ait kayıtlarda, alçıya döküm tekniğiyle şekillendirmenin gerçekleştirildiği yazılmaktadır. Ancak öncesinde heykeltıraşların figürleri işlediğini ve bunların çok parçalı küçük kalıplar ve dışarıda bunları tutan zarf kalıp parçalarından oluştuğu yazılmaktadır. Ancak buradaki püf noktası neredeyse \%60’ı kil olmayan bir karışımda ağır partiküllerin dibe çökmesini engellemek için alçı kalıp içinde veya bekleme tanklarında sürekli karıştırılması ve çalkalanmasıdır. Ayrıca bünyenin plastik yapısının düşük olması sebebiyle kalınlığın doğru ayarlanması, sıvının kalıptan boşaltma işleminin doğru zamanlarda yapılması ve kalıp parçalarının dahi hesaplanmış sürelerde figürden ayrılması gerektiği vurgulanmıştır. Aksi takdirde bünyede yırtılmalar ve çökmeler meydana gelmesi kaçınılmazdır. Parçalı çalışmalar deri sertliği tabir edilen sertlikte yapıştırmaya uygundur. Pişirimler sagar kutularının içinde yapılır ki bu da parça üzerinde fırın içinde oluşabilecek lekelenmeleri veya kirlenmeleri önler. İlk pişirim $1050^{\circ} C^{\prime}$ 'de gerçekleşir. Figürde oluşan çatlak ve kırıklar frit ve bünyenin kendisiyle yapılan bir karışımla tamire ihtiyaç duyuyorsa bu tamirler yapılır ve $1200^{\circ} \mathrm{C}$ 'de tekrar firınlanırlar. Bu pişirimler 60 ila 70 saat arası sürmektedir. Toplam küçülme \%25'tir.

1855 tarihli, geliş̧irilmiş olduğu düşünülen bir reçetenin içeriği de şöyledir;

'Frit; kalsine edilmiş ve iyi öğütülmüş'

100 lbs Yıkanmış Wight Adası Kumu 16

60 lbs Feldspat

20 lbs Potas

'Bünye; iyi öğütülmüşs'

$\% 40$ China Clay

\% 20 Kalsine Feldspat

\%20 Ham Ögütülmüş Feldspat

$\% 13.3$ Frit

\%6.7 Cam. (Copeland, 2007: 56)

Parian Ware kitabında ise Dennis Barker her firmanın farklı reçeteler kullandığını belirtmiş ve Copeland \& Garrett'ın reçetesini aşağıdaki gibi vermiştir;
'Frit'

57 kısım Beyaz Kum

11 kısım Cornish Stone (Pegmatit)

8 kısım Potas

'Bünye'

36 kısım China Clay

40 kısım Feldspat

24 kısım Frit

Feldspattaki demir oksit oranı bünyenin rengini belirler (Barker, 1985: 6).

Copeland'ın reçeteleri konuya ilişkin araştırmada en çok rastlanılan reçetelerdir. Copeland ile yakın zamanda üretime başlayan Minton ve diğer firmaların da reçeteleri farklılıklar gösterir. Bunların çoğu ticari sır olarak saklandığı veya kısmen kayda geçirildiği için diğer firmaların çoğuna ait reçeteler günümüze ulaşmamıştır. ${ }^{17}$

\section{Parian Bünyesine Atfedilen İsimler}

Önceki bölümde de bahsi geçtiği üzere, bu dönemde İngiltere'deki üreticilerin büyük bir kısmı figür üretimini bone-china bünye ile sınırlandırmışlardır. Bu bünye ise aslında teknik ve ticari olarak bu tip üretime uygun değildir ve eski tip yumuşak porselen bünyesinin lezzetine de ulaşamamaktadır. Tam da bu dönemde Copeland firması tarafından uzun uğraşlar sonucunda elde edilen bünye üreticilerin imdadına yetişmiştir. Hem ticari olarak daha az maliyetli hem de karmaşık kompozisyonlardaki figür gruplarını dahi üretmede zorluk yaşatmayan yeni Parian bünyesi uygulamalı sanatlara ait örnekler arasında seri üretime yatkınlığı ve ticari başarısı açısından en önemli örneklerden biridir (Dickinson, 2009: 92). Parian ismini ilk kullanan firma Minton'dur. Copeland 'porselen heykel' (statuary porcelain), Wedgewood 'Carrara' isimlerini kullanmıştır. Bu heykeller ticari olarak piyasaya sürüldüklerinde 'sanat objeleri' olarak tanıtılmışlardır ve asla salt dekoratif objeler olarak lanse edilmemişlerdir. Tüketicinin aklına yerleştirilen kavram da bunların ister birer sanat objesi olarak sergilenmeleri istenirse de dekoratif özellikleriyle ön plana çıarılabilmeleridir (Dennis 1989, Dickinson 2009: 100'den). Parian figürlerini üretenler Sanat Birliği'nin ihtiyacına da bu bakış açısıyla karşılık vermiş ve uzun yıllar 
boyunca Sanat Birliği’ne ait etkinliklerde çok sayıda dağıtılmışlardır.

\section{Londra Sanat Birliği'nin ve 1. Dünya Sergisi'nin Parian Por- selenlerinin Tanınmasına Olan Katkıları}

Londra Sanat Birliği, sanatçılarla olan ilişkisi ve destekleri açısından İngiliz sanat tarihine katkı yapan önemli kuruluşlardan biri olarak görülür. İngiltere'de sanatı sadece zenginlerin değil orta sınıftakilerin de yaşam pratiğine dâhil etmiş, hamiliklerin sadece soylular tarafından değil aynı zamanda sıradan zenginlerin veya maddi anlamda standart refah düzeyinde olanların da yapabileceğini göstermiş ve sanatın gündelik hayatın bir parçası olmasını sağlamıştır (Dickinson, 2009: 197).

Parian'ın döneminde bu kadar popüler olmasının sebeplerinden biri de Sanat Birliği tarafından önemli ölçüde teşvik edilmiş olmasıdır. Parian porselen bünyesinin icadı 1836'da Sanat Birliği'nin kuruluşunun hemen ardından gelir. Birliğin amacı, sanatın teşvik edilmesi ve geliştirilmesiyle halkın zevkinin de geliştirilmesi ve medeni anlamda ilerleme kaydetmektir. Ayn zamanda sanatsal etkinliklere destek olmak amacıyla piyangolar ve özel etkinlikler düzenleyerek halkın 'tüm sınıfları' arasında sanatı sevdirmek ve öğretmektir (Barker, 1985: 11). Birlik 1838'de üyelere ve üye olacak kişilere, Maclise'in 'The Meeting of Wellington and Blucher after the Battle of Waterloo' isimli orijinal gravürünü hediye etmeyi taahhüt etmiştir. 1842'deki yıllık piyango çekilişinde ise ödül olarak bronz heykelciklerin verilmesi kararlaştırılmıştır. Bu, birliğe olan ilgiyi artırmak adına başarılı olmuştur; öyle ki birlik devamındaki dönemde heykel sanatına destek olmak ve daha düşük maliyetli heykeller ürettirmek adına Messrs Copeland \& Garrett'ın ürettiği Parian figür heykellerini promosyon öğesi olarak kullanmaya karar vermiştir (Hurtado, 1993: 10). 1845'teki Manchester Endüstriyel Sanatlar Sergisi'nde, Copeland \& Garrett'ın standı dönemin yazar ve eleştirmenleri tarafından övülmüştür. Bundan sonra da Parian figür heykelleri Sanat Birliği etkinliklerinin hep merkezinde yer almışlardır (Barker, 1985: 11). Sanat Birliği'nin bu tutumu, İngiltere'de Neoklasik dönemin de insanlar üzerinde yarattığı yeni he- yecanlar sayesinde, sanata ve kültür değeri taşıyan her şeye olan ilginin sıradan halk arasında da artmasını sağlamıştır. Bu sayede sanat eserlerine özellikle de baskı resim ve figür heykel gibi seri üretilebilir sanat eserlerinin ticari başarıları sağlamlaşmıştır. Liverpool, Manchester gibi şehirlerdeki sanat birlikleri de Londra örneğindeki gibi hareket etmişler ve figüratif porselenleri veya seri üretilebilir baskı resimleri üyelerine hediye ederek yaygınlaşmalarını sağlamışlardır.

1. Dünya Sergisi (The Great Exhibition of London) ise plastik sanatların ve ticaretin birlikteliğini kutlamıştır adeta. Bu sergide sanat ve zanaat pazarının her türlü ürününü görebilmek mümkündü. Özellikle Parian porselen bünyeli figüratif heykeller, çeşitli seramik figürler, bronz heykeller, altın ve gümüş işçiliğinin zirve yaptığı figürlü eşyalar, fildişi heykeller ve mermer anıt heykeller ve içinde figür barındıran pek çok eser burada görücüye çıkmıştı. Bu sergide klasik üslupta yapılmış pek çok eser yer alsa da Parian figürler serginin en çok dikkat çeken eserlerindendi, öyle ki heykeltıraş John Gibson'ın mermerden birebir boyutlarda yapmış olduğu Avcı ve Köpek (Hunter and Dog- Yunan Avcı) isimli heykeli, aynı sanatçının Narkisos'un Parian bünyesinden yapılmış eserinden daha az ilgi görmüştü (Resim 7) (Droth, 2004:226). 1862 yılındaki Büyük Londra Fuarında da (1862 Great London Exposition) Rafaelli Monti'nin Copeland firması için modellediği 'Gece' isimli figüratif heykel sanatçısının becerisini sergiler nitelikteydi ve tüm dikkatleri üzerinde toplamıştı. Aslında, Monti'nin Thomas Battam tarafından bir yıl önce düzenlenen Crystal Palace Sanat Birliği etkinliği için yapmış olduğu ve Copeland tarafından üretilen 'Gelin' isimli büstü, Parian figüratif heykelleri arasında dönemin en popüler ve bilinen eseri haline gelmişti (Resim 8) (The Fitzwilliam Museum).

Tüm bu pazarlama, promosyon ve popülerlik ilişkisinde, Parian figüratif heykelleri sıradan halk arasında bile bir statü sembolü olarak görülmeye başlanmış ve büyüyen ilgi sayesinde sanat pazarının en önemli metası haline dönüşmüştür. Bu heykellerin böylesine yaygınlaşmasını sağlayan en önemli kişilerden biri de Benjamin Cheverton'dır. 


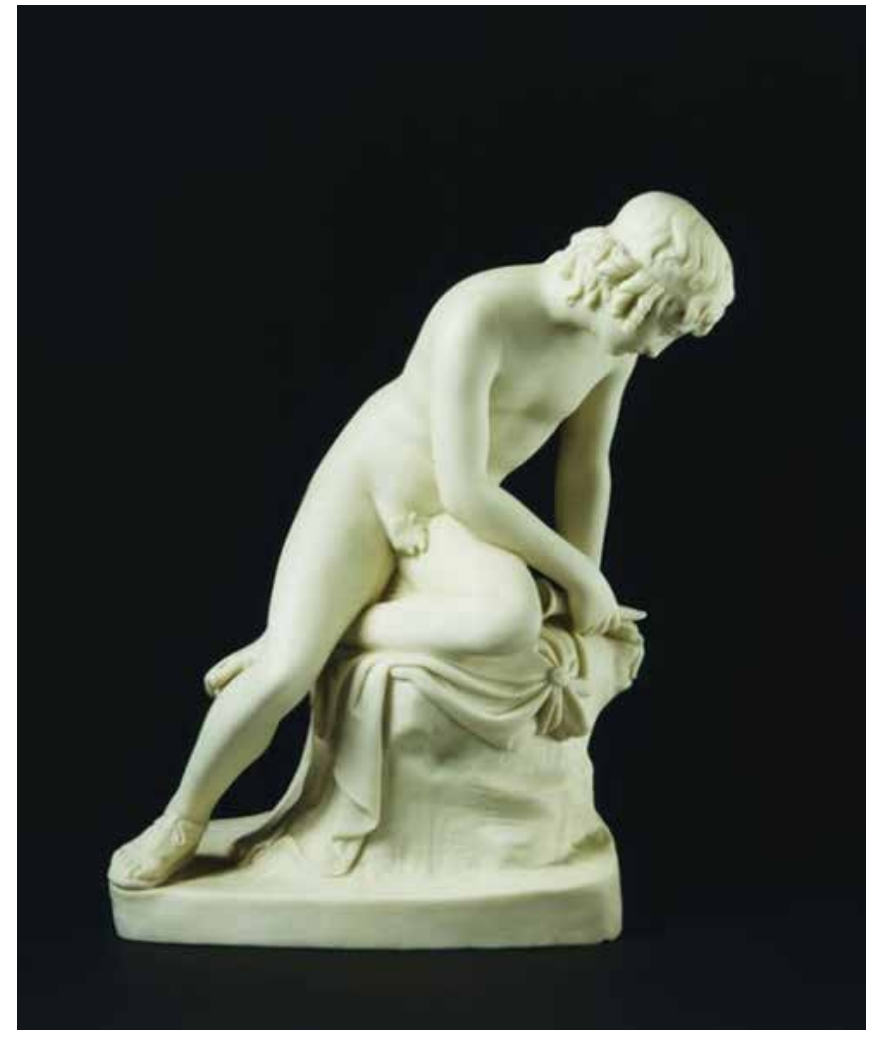

Resim 7. John Gibson'ın Copeland firmasında üretilen ünlü Narkisos heykeli. 30,2 × 24,2 cm. 1846
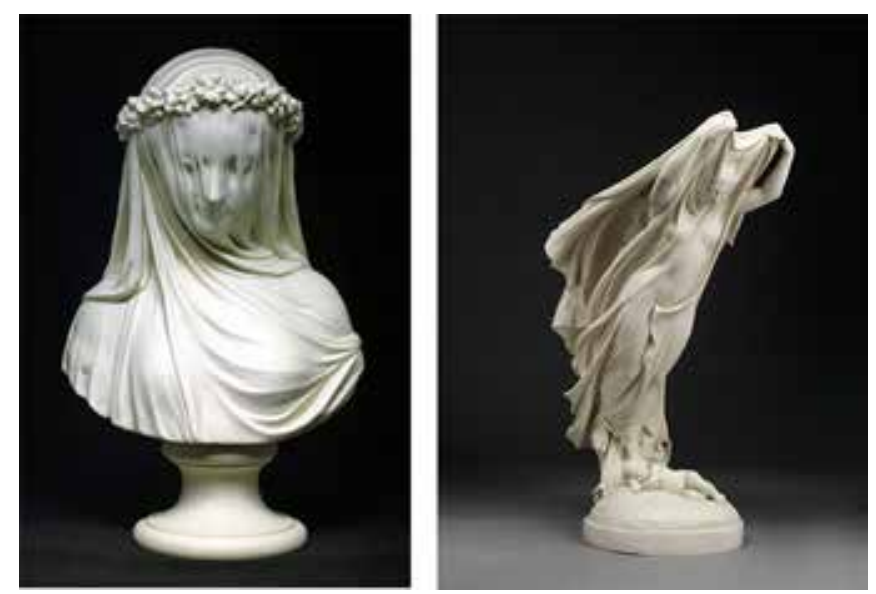

Resim 8. Rafaelle Monti'nin Copeland firması için modellediği 'Gelin' (solda- yükseklik $38 \mathrm{~cm}$ ) ve 'Gece' (sağda- yükseklik 46,6 $\mathrm{cm}$ ) isimli heykelleri.

\section{Benjamin Cheverton'in Pantografı} ve Porselen Heykel üretimine Katkıları

Parian porselen heykellerinin üretimine ilişkin en çarpıcı olaylardan birisi, Benjamin Cheverton'un pantografıdır. ${ }^{18}$ Bu pantografı öncülerinden ayırt eden en büyük özelliği üç boyutlu bir objeyi tanımlamasındaki becerisiydi (Resim 9). Cheverton'ın 'küçültme makinesi' (reducing machine) ismiyle anılan üç boyutlu pantografı, pek çok klasik dönem heykelinin küçültülerek kopyalanmasına ve Parian bünyesiyle üretilmesine olanak sağlamıştır. Bu makine olmaksızın 'porselen heykellerin' İngiltere'de bu denli yaygınlaşması ve beğenilmesi olanaksızdı. Bu cihaz hangi materyalden yapılırsa yapısın bir modelin hacimsel oranlarını başka bir malzemeye indirgenmesini sağlayabilmekteydi. Daha sonra da küçültülen modelin alçıdan kalıbı alınıyor ve döküm yöntemiyle çoğaltılabiliyordu. Aynı zamanda 1851'deki 1.Dünya Sergisi'nde de ödül alan bu cihaz, İngiltere'deki orta sınıfın evlerine pek çok usta heykeltıraşın eserlerinin girmesini ve sanat eserlerinin popülerleşerek yaygınlaşmasını, heykeltıraşların da sanat pazarındaki erişiminin artmasını sağlamıştı (Dickinson, 2009: 116-121).

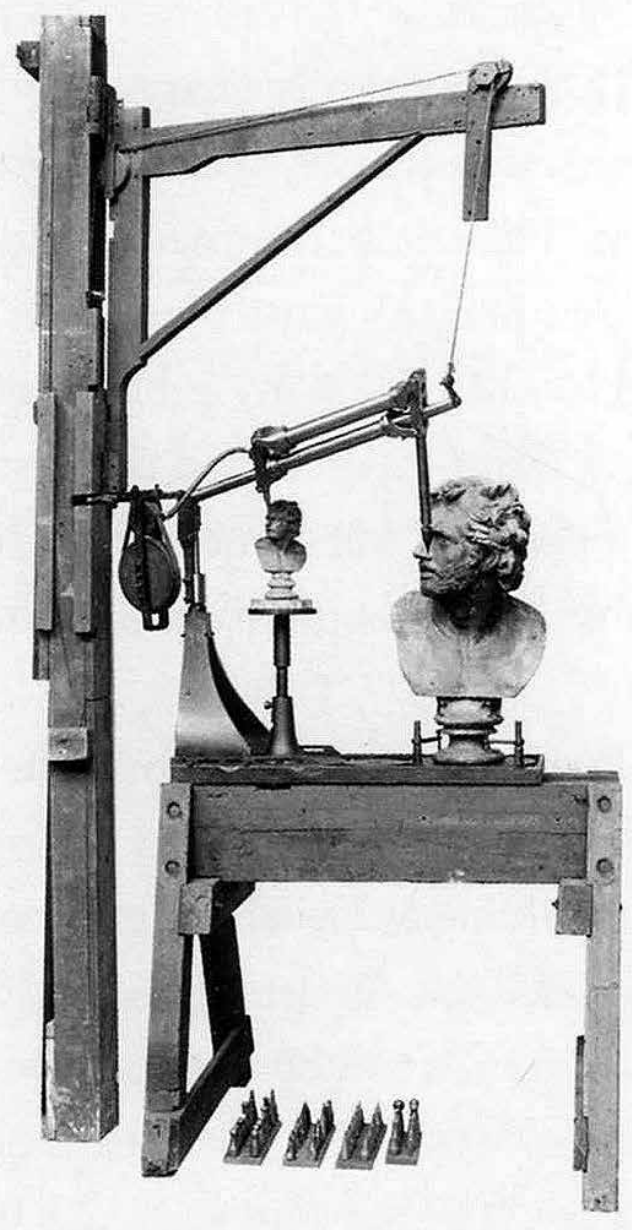

Resim 9. Benjamin Cheverton'un pantografı. 


\section{Sonuç ve Değerlendirme}

Parian figüratif heykelleri gerek ticari olarak, gerekse üretim pratiği ve teknolojisi olarak döneminin ötesinde bir yere konumlandırılabilir. Sanat eserlerinin, özellikle heykellerin evlere girmesiyle kişilerin bu eserleri çevresine göstererek sınıfsal veya kültürel statüsünü paylaşmasının önemli olduğu bir ortamda Parian porselen heykelleri tam da bu ihtiyacı karşılayacak türden ticari eserlerdi. Ona sahip olmak bir statü sembolüydü ve istenilen kişinin veya klasik dönem heykelinin, istenilen sanatçı tarafından yorumlanmış versiyonlarına ulaşmak da mümkündü. Hepsinin arka planında, belki de böylesine yüksek nitelikte eserlerin üretim maliyetinin düşük olması sebebiyle piyasada ucuza bulunabiliyor olması durumu yatıyordu. Ayrıca İngiltere'nin özellikle Neoklasizme ve Victorian Dönem'deki dekoratif sanatlara olan yüksek ilgisi ve sanat koleksiyonculuğunun yaygınlaşması da bu talebi körüklemiştir. İngiltere'de, sanat eseri koleksiyonuna olan bu ilgisinin en önemli sebeplerinden biri de 'The Grand Tour' olarak anılan, on altıncı yüzyılın sonlarından ve on dokuzuncu yüzyılın ortalarına kadar süregelen bir kültür-eğitim gezi programıdır. Bu dönemde, genç aristokratlar için Paris'i, Venedik'i, Floransa'yı ve Roma'yı gezmek ve buraya ait kültürü yerinde incelemek moda haline gelmişti ve bu da Grand Tour'u yaratma fikrini doğurmuştu. Böylece, İngilizler, Almanlar, İskandinavlar ve hatta Amerikalılar, Fransız ve İtalyan sanatıyla yerinde tanışıyor ve bu kültürel aktarımı tecrübe ediyorlardı. Londra bu seyahatin başlangıç noktası olarak kabul görmekle beraber oluşturulan farklı rotalar Türkiye'ye kadar uzanıyordu. Bu seyahatler, aynı zamanda modern arkeolojinin ve sanat tarihinin babası sayılan Johann Joachim Winckelmann'ın öncülüğünde Neoklasizmin doğuşunu da desteklemiştir. Grand Tour sadece bir eğitim ve gezi programı değildi. Bu tura katılan aristokrat gençler seyahat ettikleri yerlerde sanat eserleri yaptırıyor veya satın alıyorlardı. (Sorabella) Ayrıca Herculaneum ve Pompeii kazı alanlarının ortaya çıkışı, on sekizinci yüzyılın en önemli arkeolojik keşifleri olarak Avrupa'da karşılık bulmuştur. Burada bulunmuş pek çok eser, Neoklasik üslupta çalışan sanatçı ve tasarımcılara ilham vermiş ve Neoklasik dönemin etkisi Avrupa'daki tüm porselen üreticilerine de yansımıştır. Ancak Sévres ve Meissen gibi öncü üreticiler genellikle vazo üretimine ağırlık vermiş̧ler, üslubun karakteristik özelliklerini daha çok iki boyutlu yüzeyler üzerinde resimsel anlatım ve kompozisyonlarla değerlendirmişlerdir. 19

İngiliz porselen üreticilerini Avrupa'daki diğer öncülerinden ayıran en büyük özelliklerden biri de kurulan işletmelerin büyük çoğunluğunu şahıs şirketleri oluşudur. Bu açıdan bakıldığında endüstriyel anlamda sanat üretimi yapanların hamiliklere ve soyluların desteklerine ihtiyaç duymaksızın özerk bir yapılanmaya girişmiş olmaları açısından önemlidir. Figüratif heykellerin yakalamış olduğu bu başarı Atlantik'in diğer kıyısında da karşılık bulmuştur. Amerika Birleşik Devletleri'ne yerleşen bazı sanatçılarla beraber bu figüratif heykellerin üretimi İngiltere'yle eş zamanlı olarak burada canlanmış ve benzer üretimler yapılmıştır. Amerika'da Parian heykelleri ilk olarak 1853'te Christopher Webber Fenton tarafından Bennington-Vermont'ta üretilmiştir (Levin, 1988: 39). Diğer önemli üreticiler ise Ott \& Brewer, Edwin Bennet, Chesapeake Pottery (Cameron, 1986: 225) ve Greenpoint-New York'taki Charles Cartlidge firmasıdır. Amerika Birleşik Devletleri'nde de aynı İngiltere'de görüldüğü üzere George Washington gibi politik figürler ve Shakspeare gibi sanatçıların portreleri en çok talep gören figürler arasında yer almıştır (Barker, 1985: 28). Genel üretime bakıldığında ise piyasada oldukça fazla sayıda kötü örneklere de rastlamak mümkündür. Bu örnekleri üreticiler isimlerini kullanmaksızın piyasaya sürmüşlerdir.

Gerek İngiltere'de gerek Amerika'da olsun üretilen nitelikli heykelcikler, seri üretilebilir sanat-tasarım ürünlerinin görücüye çıktı̆ı̆ Dünya Fuarları'nda ${ }^{20}$ sergilenen önemli yapıtlar olmuşlardır. Önemli üreticileri Copeland, Minton, Worcester, Wedgwood, Goss ve Robinson and Leadbeater olan bu eserlerin üretimi 1939 yılına kadar aktif olarak sürmüş, Victorian Dönem estetiğinin kitsch bulunmasıyla beraber üretimi yavaş yavaş sonlandırılmıştır (Dickinson, 2009: 93). İrlandalı Belleek fabrikası ise halen Parian bünyesiyle üretimini sürdürmektedir. Günümüzde nitelikli parçaların müzayedelerde yüksek fiyatlara alıcı bulduğu bu eserler, seramik ve heykel disiplinin bir arada görüldüğü eşsiz örnekler sunmuştur. 


\section{Notlar}

1 Orta sınıfın ve burjuvazinin bu gelişimi ve devamındaki sanat ve zanaat eserlerine olan ilginin yükselişi yine bir ada ülkesi olan Japonya'da Edo Dönemi'nde görülür (16031868). Japonya bu dönemde ticaret, tarım ve endüstri anlamında aynı İngiltere'de olduğu gibi büyük bir atılım gerçekleştirmiştir. Çin'de Ming Hanedanlığı'nın çöküşüyle birlikte Avrupa'ya Uzakdoğu'dan yapılan porselen başta olmak üzere dekoratif ürünlerin ihracatında Japon İmparatorluğu lider konumdadır. Bu durum Japonya'da el sanatlarının gelişmesine de ekstra bir katkıda bulunmuştur (Tashiro \& Videen, 1982).

2 Sert porselen Avrupa'da ilk olarak Almanya-Meissen'de 1713'de Böttger tarafından bulunmuştur. İngiltere'de sert porselen bünyelerin üretiminden önce yumuşak porselen, bone china gibi farklı tipte porselen bünyeler üretilmiştir. 1768'de William Cookworthy İngiltere'yi sert porselenle tanıştırmış olmasına rağmen, Josiah Spode tarafından geliştirilen bone china bünye İngiltere'de porselenin neredeyse terminolojik karşılığı olarak kullanılmış ve üreticiler tarafından tercih edilmiştir (Cox, 1944). Avrupa'daki diğer ülkelerde porselen üretimi soyluların ve kralların himaye ve sponsorluklarında üretilmiştir ancak İngiltere'de üreticilerin tamamı serbest girişimcilerden kuruludur ve çok ortaklıdır. Ekonomik koşullardaki istikrarsızlıklar ve sürekli ortaklıkların el değişmesi gibi sebepler de bu duruma eklenince İngiltere'de yumuşak porselen üretimi bile kıtanın diğer üreticilerinin otuz yıl gerisinden gelir (Dickinson, 2009: 4647).

3 Antik dönem heykeline olan tutku on yedinci yüzyılın ikinci yarısından sonra Avrupa'da en çok İngiltere'de görülmüştür, bunun en önemli sebeplerinden biri de koleksiyonerlerin hatırı sayılır miktarda Klasik üslupta yapılmış mermer heykelleri ithal etmeleri ve bu koleksiyonerlerin arasında soyluların başı çekmesidir. Ressam Benjamin Robert Haydon, 1812'de İngiltere'deki sanat ortamına ilişkin görüşlerini otobiyografisinde anlatırken tüm kiliselerin ve devlet binalarının heykellerle tıka basa doldurulduğunu ve bunların resim sanatı için birer utanç abidesi olduğunu, bunun başka hiçbir ülkede bu denli şımarıkça yapılmadığını yazmıştır (Whinney, 1992: 361).

4 Bone China: İçinde yüksek miktarda kemik külü (kalsiyum fosfat) barındıran yumuşak ve sert porselen arası sınıflandırılmış, İngiltere'de bulunmuş ve geliştirilmiş bir porselen bünye çeşididir. Bilinen en genel reçetesi, 40 kısım kemik külü, 32 kısım china clay, 28 kısım chinastone (pegmatit)'dan oluşur (Fournier, 1992: 26-27).

5 Parian mermeriyle yapılmış heykeller arasında Laocoon Grubu, Medici Venüsü ve Semadirekli Nike yer alır. Bu mermer yarı saydam yapısı ve yüzey etkisi sebebiyle Antik Yunan heykellerinden Napoleoun'un mezarına kadar pek çok eserde heykeltıraşların tercihi olmuştur.

6 On sekizinci yüzyılın ortalarında, Vincennes-Sévres'de sırsız porselenin küçük ölçekli heykellerin yapımında kullanılmaya başlanmasıyla Avrupa seramiklerinde yeni bir kategori oluşmuştur. Bu fikir ilk olarak 1752'de Vincennes'e sanat direktörü olarak atanan Fransız Ressam Jean-Jacques Bachelier tarafından ortaya atılmıştır (Dickinson, 2009: 15). Herculaneum ve Pompeii'deki kazılar da klasik döneme ilgiyi artırmış ve bisküvi porselenin mermere olan yüzeysel benzerliği de bu döneme ait objelerin reprodüksiyonuna uygun olduğu görüş̧ünün ortaya çıkmasına sebep olmuştur (Dickinson, 2009: 18).

7 Kaynakların geneline bakıldığında bünyenin 1842'de üretildiği, 1846 'da ise piyasaya etkin şekilde çıkış yaptığı görülür.

8 Hafif sırlı olarak bahsedilen yüzeyi yazar 'smear glazed' olarak tanımlar. Bunun karşılığı, sırın fırın içinde buharlaşması sonucu yüzeyde bıraktığı ince parlak katmandır (Wordnik).

9 Pâte-sur-pâte: İlk olarak Sévres'de geliştirilen bu teknik, renksiz porselen desenlerin dekupe edilerek daha koyu veya sırlı bir yüzey üzerine rölyef olarak uygulanmasıyla gerçekleştirilir. İngiltere'de Minton ve Wedgewood seramik fabrikaları bu tekniğin çok başarılı örneklerini gerçekleştirmişlerdir (Cameron, 1986: 256).

10 Stoneware: Plastik ve refrakter özelliklere sahip, sekonder yataklardan elde edilen, $1300^{\circ} C^{\prime}$ 'ye kadar pişirilebilen kil (Fournier, 1992: 274).

11 Stonechina: İngiltere'de Staffordshire'lı çömlekçiler tarafından on dokuzuncu yüzyılda geliştirilmiş, pekişmiş feldspatik bir seramik bünyedir. Yoğun, sert ve dayanıklı olarak tanımlanır ve yarı-porselen, opak porselen, İngiliz porseleni, stonechina ve newstone adlarryla bilinir (Encyclopedia Brittannica).

121849 tarihli Art Journal'ın 18. Sayfasında College of Civil Engineers (inşaat mühendisliği yüksekokulu) kurumu, J.A. Philips'i pişmiş Parian bünyesini analiz etmesi için görevlendirmiş ve tablodaki reçetenin aynısı kayıt altına alınmıştır (Dickinson, 2009: 109).

13 Lbs: Libre's kelimesinin kısaltmasıdır. Pound anlamına da gelir. 1 pound 0,4535924 grama karşılık gelir.

14 Lynn Kumu: Metnin orijinal dilinde Lynn Sand. Bu hammadde o bölgede çıkarılan doğal kuvarstır.

15 Doğada en saf haliyle bulunan kaolin çeşididir. Kimyasal formülü $\mathrm{Al}_{2} \mathrm{O}_{3} \cdot 2 \mathrm{SiO}_{2} \cdot 2 \mathrm{H}_{2} \mathrm{O}$.

16 Wight Adası'nda bulunan bir kuvars çeşidi.

17 Farklı firmaların farklı tarihlerde kullandıkları bünye reçetelerine ulaşmak için; Copeland, R. (2007). Parian Ware: Copeland's Statuary Porcelain. New York, U.S.A.: Antique Collectors Club. 
18 Pantograf: Ölçekli çizimde veya biçimlendirmede, istenen verinin büyütülmesine veya küçültülmesine yarayan, manuel olarak kullanılan cihazdır. Mucidi Christoph Scheiner'dır.

19 Victorian Dönem'in sonlarına doğru özellikle Almanya'dakilerin başı çektiği Avrupa'daki bazı üreticiler İngiltere'deki piyasa için ucuz, sert porselen bünyede Parian tipi üretimler yapmıştır. Bazı durumlarda modeller İngiltere'de yapılmış, üretimleri birkaç küçük değişiklikle dışarıda gerçekleştirilmiştir. Bu eserlerde üreticilerin isimleri yer almamaktadır. (Barker, 1985, s. 28)

20 Bu organizasyon günümüzde 'Expo' ismiyle anılır.

\section{Kaynakça}

Barker, D. (1985). Parian Ware. Buckingamshire, Aylesbury, United Kingdom: Shire Publications Ltd.

Cameron, E. (1986). The Encyclopedia of Pottery and Porcelain, 1800-1960. New York: Fact on File.

Copeland, R. (2007). Parian Ware: Copeland's Statuary Porcelain. New York: U.S.A.: Antique Collectors Club.

Coutts, H. (2001). The Art of Ceramics: European Ceramic Design 1500-1830. Yale University Press.

Cox, W. E. (1944). The Book of Pottery and Porcelain-Volume II. New York: Crown Publishers.

Dickinson, F. (2009, March). An Analysis of The Success and Cultural Significance of Parianware Sculpture in Victorian England, Volume 1-2. Yayınlanmamış Doktora Tezi. United Kingdom: University of Lincoln.

Droth, M. (2004). "The Ethics of Making: Craft and English Sculptural Aesthetics c.1851-1900”, Journal of Design History (17/3): 221-235.

Fournier, R. (1992). Illustrated Dictionary of Practical Pottery

(3rd ed.). London: Van Hostrand Reinhold Inc.

Hurtado, S. H. (1993). The Promotion of the Visual Arts in Britain, 1835-1860. Canadian Journal of History, 28(1), 59-80.

Levin, E. (1988). The History of American Ceramics. New York: A Times Mirror Company.

Richard, D. (1989). The Parian Phenomenon, Atterbury, P. (Ed.), The Old Chapel, Shepton Beauchamp, Somerset, England, 1989.

Tashiro, K. \& Videen, S. D. (1982).“ Foreign Relations During The Edo Period: Sakoku Reexamined." Journal of Japanese Studies, (8/2): 283-306
Whinney, M. (1992). Sculpture in Britain: 1530-1830 (2nd ed.). London, United Kingdom: The Yale University Press Pelican Histor.

\section{İnternet Kaynakları}

Encyclopedia Britannica http://global.britannica.com/art/ironstone-china (Erişim Tarihi: 10/06/2015)

Sorabella, J. The Metropolitan Museum of Art: http://www.metmuseum.org/toah/hd/grtr/hd_grtr.htm (Erişim Tarihi: 22/06/2015)

The Fitzwilliam Museum http://webapps.fitzmuseum.cam.ac.uk/explorer/index. php?oid=93981 (Erişim Tarihi: 06/07/2015)

Wordnik

https://www.wordnik.com/words/smear-glaze (Erişim Tarihi: 10/06/2015)

\section{Görsel Kaynaklar}

Resim 1. 'Keçi ve arı' sürahi. Chelsea Porselen Fabrikası'nda yumuşak porselen bünyeyle 1745 yılında üretilmiştir. Emaye dekorlu eserin tasarımcısı Nicholas Sprimont'tur. http://collections.vam.ac.uk/item/08081/goat-and-bee-jugcream-jug-chelsea-porcelain-factory/

Resim 2. Chelsea Porselen Fabrikası'nda üretilmiş 'Müzik Dersi' isimli ve Derby Porselen Fabrikası'nda üretilmiş Çin figürlü Sévres tarzı porselen figür grupları. (Coutts,2001:147,151)

Resim 3. Victoria \& Albert Müzesi koleksiyonundan Neoklasik üslupta yapılmış Wedgwood markalı 'Portland Vase' ve Derby Porselen Fabrikası'na ait figürlü vazo. http:// collections.vam.ac.uk/item/08066/portland-vase-vasejosiah-wedgwood-and/ http://collections.vam.ac.uk/item/ 08091/vase-stand-and-saly-jacques-francois/

Resim 4. Prens Albert ve Kraliçe Victoria'nın büstleri. 32 x 21,1 $x 11,5 \mathrm{~cm}$. ve $29 \times 18,3 \times 11 \mathrm{~cm}$. Minton \& Co. 1862 . Victoria $\&$ Albert Müzesi koleksiyonu.

http://collections.vam.ac.uk/item/077725/queen-victoriabust-marochetti-carlo-baron/

Resim 5.Victoria and Albert Müzesi koleksiyonunda yer alan Coalport Porselen Fabrikası markalı $46 \mathrm{~cm}$ yüksekliğinde 'The Faerie Queene' (1852) ve Copeland'a ait dekoratif figürler grubu. (1851)

http://collections.vam.ac.uk/item/0306883/figure-groupcoalport-porcelain-factory/ http://collections.vam.ac.uk/ item/0308046/figure-group-copeland-co/ 
Resim 6. Louis Solon imzalı, pâte-sur-pâte tekniğinin uygulandığı altın yaldızlı şişe (1875) ve Belleek firmasına ait deniz kabuğu biçimli lüsterli Parian kâseleri (1868).

http://collections.vam.ac.uk/item/0333010/pilgrim-bottlesolon-louis-marc/ http://collections.vam.ac.uk/item/ 0344279/bowls-belleek-pottery/

Resim 7. John Gibson'ın Copeland firmasında üretilen ünlü Narkisos heykeli. 30,2 x 24,2 cm. 1846

http://collections.vam.ac.uk/item/0170840/narcissusfigure-gibson-john/

Resim8. Resim 8. Rafaelle Monti'nin Copeland firması için modellediği ‘Gelin' (solda) ve 'Gece’ (sağda) isimli heykelleri.

http://webapps.fitzmuseum.cam.ac.uk/explorer/index. php?oid=93981

http://collections.vam.ac.uk/item/0344644/night-figuremonti-raffaelle/

Resim 9. Benjamin Cheverton'un pantografı.

http://www.victorianweb.org/sculpture/reviews/cheverton. jpg 